\begin{abstract}
Wpływ charakteru pola magnetycznego na efekty leczenia osób z reumatoidalnym zapaleniem stawów doniesienie wstępne

A - opracowanie koncepcji i założeń (preparing concepts)

B - opracowanie metod (formulating methods)

$\mathrm{C}$ - przeprowadzenie badań (conducting research)

D - opracowanie wyników (processing results)

E - interpretacja i wnioski (nterpretation and conclusions)

F - redakcja ostatecznej wersji (editing the final version)

\section{Influence of magnetic field parameters on therapy outcomes in patients with rheumatoid arthritis - preliminary study}

\author{
Andrzej Kwolek ${ }^{1, A, E}$, Jolanta Zwolińska ${ }^{1,2, A-F}$, Monika Chojnacka ${ }^{1, C, D, F}$, \\ Mariusz Drużbicki ${ }^{1,2, A, B}$
}

${ }^{1}$ Instytut Fizjoterapii Wydziału Medycznego Uniwersytetu Rzeszowskiego

${ }^{2}$ Kliniczny Szpital Wojewódzki nr 2 im. Św. Jadwigi Królowej w Rzeszowie

\section{Streszczenie}

Wstęp: Pole magnetyczne jest wykorzystywane w leczeniu osób z chorobami reumatycznymi w tym z reumatoidalnym zapaleniem stawów. Istotna pozostaje wciąż kwestia doboru parametrów zabiegu w celu uzyskania optymalnego efektu terapeutycznego. Celem pracy była ocena wpływu rodzaju pola magnetycznego na dolegliwości i dysfunkcje występujące w obrębie ręki u osób z RZS.

Materiat i metody: W badaniu wzięło udział 14 osób z RZS (10 - kobiet, 4 - mężczyzn), które otrzymały skierowanie lekarskie na zabiegi magnetoterapii na okolicę rąk. Średnia wieku badanych osób wyniosła 57 lat, a średni czas trwania choroby 13 lat. Zabiegi magnetoterapii wykonywano $\mathrm{z}$ wykorzystaniem stałego lub pulsującego pola magnetycznego. U badanych oceniano stopień aktywności choroby, poziom niepełnosprawności (HAQ-20), stopień nasilenia i czas utrzymywania się sztywności porannej, poziom natężenia bólu (skala VAS), objętość ręki, obrzęk i sprawność funkcjonalną. Badanie wykonywano przed i po serii dziesięciu zabiegów magnetoterapii.

Wyniki: U wszystkich badanych osób po zabiegach odnotowano, mniejsze nasilenie i krótszy czas utrzymywania sie sztywności porannej jak też obniżony poziom bólu i ogólnej niepełnosprawności. Nie było istotnej statystycznie różnicy pomiędzy grupą leczoną polem stałym i impulsowym. Istotną statystycznie różnicę wykazano pomiędzy grupą leczoną polem stałym i przerywanym w zakresie, redukcji obrzęku, poprawy zakresu ruchu i siły mięśniowej ręki. Lepsze efekty odnotowano po zastosowaniu pola pulsującego.

Wnioski: Pole magnetyczne o charakterze pulsującym zastosowane na okolicę rąk u osób z RZS jest bardziej skuteczne w redukcji obrzęku, poprawie zakresu ruchu i siły mięśniowej ręki w porównaniu do stałego pola magnetycznego. Nie potwierdzono wpływu rodzaju pola magnetycznego na jego skuteczność w obniżaniu bólu, odczuwanej sztywności porannej i poziomu niepełnosprawności.
\end{abstract}

Słowa kluczowe:

reumatoidalne zapalenie stawów, ręka, statyczne pole magnetyczne, pulsujące pole magnetyczne 


\section{Abstract}

Introduction: Magnetic field is used in therapies designed for patients with rheumatic disorders such as rheumatoid arthritis (RA). The question of selecting adequate treatment parameters to obtain optimal therapeutic effects still needs to be answered. The purpose of the study was to assess the influence of magnetic field, depending on its nature, on problems and dysfunctions experienced in upper limbs by patients with RA.

Materials and methods: The study group included 14 patients with RA (10 females, 4 males), referred for magnetotherapy to be administered in selected areas of upper limbs. On average, the subjects were 57 years old, and the mean duration of the disorder was 13 years. Magnetotherapy was administered with the use of static or pulsed magnetic field. The patients were examined for the level of disorder, disability level (HAQ-20), severity and duration of morning stiffness, pain intensity (VAS scale), hand volume, swelling and functional capacity. The examinations were carried out before and after a series of ten magnetotherapy treatments.

Results: All the patients reported decreased severity and shorter duration of morning stiffness, reduced level of pain and general disability. There was no statistically significant difference between the groups treated with static and pulsed magnetic field. Statistically significant differences between the groups treated with static and pulsed field were observed in reduced swelling, improved range of motion and muscle strength in the upper limb. The study revealed better effects of pulsed field therapy.

Conclusions: When administered to areas within upper limbs in patients with RA, pulsed magnetic field produced better effects related to the reduction of swelling as well as improving range of motion and muscle strength in the relevant area of the body compared to static field. The findings did not confirm the relationship between the type of magnetic field and its therapeutic effectiveness in reducing pain, morning stiffness and disability level.

Key words: $\quad$ rheumatoid arthritis, upper limb, static magnetic field, pulsed magnetic field

\section{Wstęp}

Energia magnetyczna jest wszechobecna w otaczającym świecie [1]. Pole magnetyczne jest wytwarzane przez poruszające się w sposób uporządkowany ładunki elektryczne, naładowane ciała, a także przez prądy przesunięcia w dielektryku. Występuje dookoła dowolnego przewodnika z prądem, bez względu na materiał, z jakiego jest wykonany i stopień jego przewodnictwa [2].

Żywy organizm jest wyczulony na zmiany pola magnetycznego. Naturalne pole magnetyczne Ziemi wykazuje intensywność w zakresie 30-70 mikrotesli i stanowi naturalny stymulator procesów fizjologicznych żywych organizmów [3]. Jednocześnie każdy żywy organizm wytwarza własne słabe pole magnetyczne o niewielkiej wartości indukcji generowane w obrębie komórek i narządów [1]. Ta wzajemna zależność stała sie podstawą stosowania pól magnetycznych we współczesnej terapii. Ogólna definicja magnetoterapii określa ją jako wykorzystywanie leczniczego działania magnesów i urządzeń wytwarzających pole magnetyczne o różnej charakterystyce fizycznej na ustrój człowieka [2]. Terapia magnesem stałym to metoda, w której statyczne pole magnetyczne generowane jest przez magnes umocowany na ciele pacjenta, przymocowany do odzieży, poduszki, biżuterii, butów itp [4].

Mechanizm leczniczego działania pól magnetycznych na żywy ustrój nie jest jeszcze do końca poznany [2, 5]. Dowody naukowe na skuteczność działania statycznych

\section{Introduction}

Magnetic energy is present in the world around us [1]. Magnetic field is generated by uniformly moving electric charges, charged bodies as well as displacement currents in a dielectric. It occurs around any electric conductor regardless of the type of material it is made of and its conductivity [2].

A living organism is sensitive to magnetic field changes. The earth's natural magnetic field intensity is between 30 and 70 microteslas and it is a natural stimulator of physiological processes [3]. At the same time, all organisms generate their own low-induction magnetic fields in cells and organs [1]. This relationship was the basis for using magnetic fields in modern therapy. Magnetotherapy is defined as the application of magnets and devices that generate different types of magnetic field for therapeutic purposes [2]. Permanent magnet therapy involves the use of static magnetic field generated by a magnet attached to a patient's body, clothes, pillow, jewellery, shoes, etc. [4].

Therapeutic effects of magnetic fields on a living organism have not been fully explored as yet $[2,5]$. Scientific evidence regarding therapeutic effectiveness of static magnetic fields is not unequivocal. It is believed that they may be administered not only in relation to pain relief but also inflammation [6]. Issues 
pól magnetycznych są niejednoznaczne. Przypuszcza się, że oprócz działania przeciwbólowego mogą wykazywać też działanie przeciwzapalne [6]. Zagadnienia związane z wpływem pulsujących pól LF-EMF na organizm człowieka nie są ostatecznie rozstrzygnięte i wymagają dalszych badań. Szereg badań in vivo i in vitro potwierdza wpływ pulsującego pola magnetycznego na obniżenie poziomu bólu i stymulację procesu gojenia tkanki [7]. Niektórzy badacze poddają jednak w wątpliwość wpływ tych pól na procesy fizjologiczne ustroju [8]. Inni autorzy dostrzegają możliwy wpływ stałego bądź pulsującego pola magnetycznego na reakcje redox przebiegające w komórkach organizmu, co może wpływać na procesy proliferacji lub apoptozy komórek [9].

$\mathrm{Z}$ przeglądu literatury wynika, że niewiele prób klinicznych dotyczących działania statycznego pola magnetycznego wytwarzanego przez magnesy stałe cechuje się wysoką jakością metodologiczną stąd wyniki tych prób nie mogą stanowić twardych dowodów naukowych na skuteczność takiej terapii $[6,10]$. W związku z tym istnieje potrzeba realizacji randomizowanych, kontrolowanych badań (RCT) w celu oceny i porównania efektywności stałego i pulsującego pola magnetycznego.

Celem badania była ocena wpływu charakteru pola magnetycznego na dolegliwości i dysfunkcje w obrębie ręki u osób z reumatoidalnym zapaleniem stawów.

\section{Materiał i metody}

Zgodę na realizację projektu badawczego: „Wpływ terapii pulsującym i ciągłym polem magnetycznym na stan ręki u pacjentów $\mathrm{z}$ reumatoidalnym zapaleniem stawów" wyraziła Komisja Bioetyczne przy Uniwersytecie Rzeszowskim (Uchwała nr 2/06/2011 z dnia 1 czerwca 2011).

W badaniu wzięło udział 14 osób (10 kobiet, 4 mężczyzn) z reumatoidalnym zapaleniem stawów (II i III stopień zaawansowania zmian radiologicznych, 2 i 3 stopień zaawansowania zmian funkcjonalnych oraz mały i umiarkowany stopień aktywności choroby według DAS 28). Wszystkie zakwalifikowane osoby posiadały skierowanie lekarskie na zabiegi magnetoterapii na okolicę rąk i standardową kinezyterapię (grupa ręki). W okresie pomiędzy badaniem wstępnym a badaniem kontrolnym badani nie stosowali innych zabiegów fizjoterapeutycznych na okolicę rąk. Ponadto $\mathrm{W}$ okresie pomiędzy badaniem pierwszym i kontrolnym nie zmieniali rodzaju ani dawki stosowanej farmakoterapii oraz wyraziły zgodę na udział w badaniach. Z badań wyłączone zostały osoby, u których istniały przeciwwskazania do stosowania magnetoterapii (głównie zaburzenia ze strony układu krążeniowo - oddechowego) oraz te, które nie ukończyły programu badawczego.

Średni wiek badanych wyniósł 57 lat, a średni czas trwania choroby 13 lat. associated with the effects of pulsed LF-EMF on a human body have not been addressed in detail and they require further research. A number of in vivo and in vitro studies confirm the relationship between pulsed magnetic field and therapeutic effectiveness in reducing pain and enhancing the tissue healing process [7]. However, some researchers are sceptical about the effects of these fields on physiological processes [8]. Others notice a possible relationship between static or pulsed magnetic field and redox reactions that occur in cells, which may affect cell proliferation or apoptosis [9].

A literature review revealed that few clinical trials on static magnetic field generated by magnets were of high methodological quality. Hence, their findings cannot be treated as hard scientific evidence of the therapy effectiveness $[6,10]$. It is therefore necessary to carry out randomised controlled trials to assess and compare the effectiveness of static and pulsed magnetic fields.

The purpose of the study was to assess the influence of magnetic field on disorders and dysfunctions of upper limbs experienced by patients with rheumatoid arthritis (RA).

\section{Materials and methods}

The project "The influence of pulsed and static magnetic field on upper limbs of patients with rheumatoid arthritis" was conducted in accordance with the approval from the Bioethics Committee of the University of Rzeszow (Act No. 2/06/2011 of 1st June 2011).

The study group consisted of 14 patients (10 females and 4 males) with RA (stages 2 and 3 of radiological changes, stages 2 and 3 of functional changes, low and moderate disease activity according to DAS 28). All the participants were referred for magnetotherapy and standard kinesiotherapy to be administered in selected areas of upper limbs. Between the preliminary and control examinations, the participants did not undergo any other therapeutic treatments in upper limbs. Moreover, between the first and the control examination, they did not change the type or dose of pharmacotherapy and they gave their consent to participate in the study. Individuals with contraindications to magnetotherapy (cardiovascular and respiratory system disorders) as well as those who did not complete the examination procedure were excluded from the study.

On average, the subjects were 57 years old, and the mean duration of the disorder was 13 years.

The study involved a subjective evaluation of patients regarding: 
Badanie obejmowało subiektywną ocenę pacjenta dotyczącą:

- nasilenia i czasu utrzymywania się sztywności porannej (nasilenie sztywności oznaczano w skali od 0 do 100, gdzie 0 oznaczało brak sztywności a 100 sztywność maksymalną)

- poziomu nasilenia bólu (skala VAS 0-100)

- poziomu ogólnej niepełnosprawności (kwestionariusz HAQ-20).

Do oceny sprawności ręki wykorzystano komputerowe stanowisko pomiarowe. Przy wykorzystaniu klatki pomiarowej wyposażonej w czujnik fotoelektryczny dokonywano pomiaru powierzchni dłoniowej ręki wyrażonej w mm2. Oceniono również objętość chwytu wyrażając ją jako objętość powietrza wypartego z cylindra pomiarowego podczas chwytu cylindrycznego. Wyparte powietrze powodowało przemieszczenie mieszka w naczyniu połaczonym $\mathrm{z}$ cylindrem pomiarowym. Przemieszczenie to wyrażone w milimetrach bieżących stanowiło miarę zakresu ruchu w stawach ręki. Siłę ścisku globalnego ręki wyrażono wartością ciśnienia wytworzonego pod wpływem ścisku w cylindrze pomiarowym zmierzoną czujnikiem ciśnienia $(\mathrm{kPa})$. Uwzględniono też czas utrzymywania się maksymalnej siły ścisku ręki. Odmierzano czas, w którym maksymalna wartość siły ścisku ręki obniżyła się o ponad 20\% (Ryc. 1)
- $\quad$ severity and duration of morning stiffness - stiffness severity was rated from 0 (no stiffness) to 100 (maximum stiffness);

- pain intensity (VAS 0-100)

- disability level (HAQ-20).

Hand mobility was assessed using a computer measurement station. Palmar surface area expressed in $\mathrm{mm} 2$ was measured using a measuring frame equipped with a photoelectric sensor. The grip volume was also measured, and it was defined as the volume of air displaced from a measuring cylinder during a cylindrical grip. The expressed air brought about the displacement of a bubble in a vessel connected to the measuring cylinder. This displacement, expressed in millimetres, was a measure of a range of motion in the joints of the hand. Grip strength was defined as a value of pressure created by grasping the measuring cylinder and measured with a pressure sensor $(\mathrm{kPa})$. The duration of sustained maximal cylindrical grip strength (until the grip strength decreased by more than 20\%) was also measured (Fig. 1)

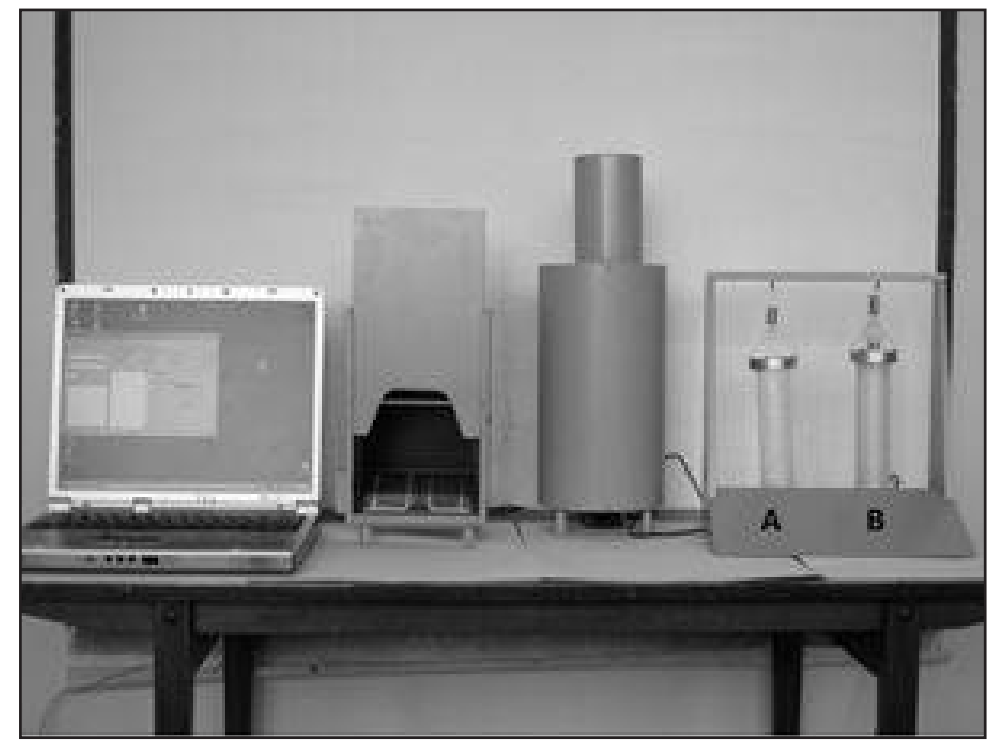

Ryc.1.Komputerowestanowiskopomiarowedooceny funkcjiręki.Dokładnośćpomiarowaczujnikówwykorzystanychdopomiarówkomputerowych wynosiła $\pm 0,1 \%$ dla czujnika ciśnienia - A i $\pm 0,2 \%$ dla czujnika przemieszczenia - B (pomiaru zakresu ruchu) [11].

Fig. 1. The computer measurement station used for evaluating functional capacity of the hand. Measurement accuracy of the sensors was $\pm 0.1 \%$ for the pressure sensor - $\mathrm{A}$ and $\pm 0.2 \%$ for the movement sensor - B (range of motion measurement) [11]

Przy wykorzystaniu zestawu do pomiaru objętości cieczy wypartej z naczynia po zanurzeniu kończyny dokonywano pomiaru objętości ręki.

Dokonywano pomiaru czasu wykonania testu zadaniowego polegającego na umieszczeniu 18 - stu pla-
Hand volume was determined using equipment for measuring the volume of liquid displaced from the vessel after limb immersion.

The study participants were asked to perform a task that involved inserting 18 plastic pegs into the board holes and putting them back into a container. The bo- 
stikowych kołeczków w otworach planszy i ponownym zebraniu ich do pojemnika. Plansza z otworami leżała na blacie stołu bezpośrednio przed pacjentem. Pojemnik z kołeczkami znajdował się przy planszy po stronie badanej ręki.

Terapia badanych osób polegała na przeprowadzeniu usprawniania ruchowego i serii zabiegów magnetoterapii. Osoby zakwalifikowane do badania zostały podzielone na dwie grupy (randomizacja poprzez rzut monetą). W grupie pierwszej (8 osób/16 rąk) zastosowano stałe pole magnetyczne, a w grupie drugiej (6 osób/12 rąk) pulsujące pole magnetyczne. Zabiegi wykonywano aparatem MF-10 generującym pole stałe (przebieg V) i pole pulsujące (przebieg II czyli prostokąt bipolarny o częstotliwości zmian $15 \mathrm{~Hz}$ ). W przypadku obu przebiegów maksymalna wartość indukcji pola magnetycznego wynosiła 5,25 mT.

Badanie przeprowadzono dwukrotnie: przed terapią i po jej zakończeniu.

Do analizy statystycznej otrzymanych wyników wykorzystano:

- $\quad$ statystyki opisowe

- Test Wilcoxona do oceny istotności zmian zachodzących w wyniku leczenia

- Test Manna-Whitneya do oceny wpływu charakteru pola na efekty leczenia.

Za wyniki istotne statystycznie uznano wartości $p<0,05$.

\section{Wyniki}

W tabeli zbiorczej zawarto charakterystyki opisowe efektów leczenia w obu porównywanych grupach wraz z oceną istotności różnic pomiędzy grupami dokonaną za pomocą testu Manna-Whitneya (tab. 1)

Tab. 1. Efekty leczenia w obu porównywanych grupach

\begin{tabular}{|c|c|c|c|c|c|c|c|c|c|}
\hline \multirow{3}{*}{$\begin{array}{l}\text { Efekty } \\
\text { leczenia }\end{array}$} & \multicolumn{8}{|c|}{ Pole magnetyczne stałe/pulsujące } & \multirow{3}{*}{$p$} \\
\hline & \multicolumn{4}{|c|}{ stałe } & \multicolumn{4}{|c|}{ pulsujace } & \\
\hline & $N$ & & $\mathrm{Me}$ & $s$ & $N$ & & $\mathrm{Me}$ & $\mathrm{s}$ & \\
\hline $\begin{array}{l}\text { Czas sztyw- } \\
\text { ności poran- } \\
\text { nej [min.] }\end{array}$ & 8 & $-37,5$ & $-30,0$ & 41,7 & 6 & $-21,7$ & $-20,0$ & 23,2 & 0,6620 \\
\hline $\begin{array}{l}\text { Stopień nasi- } \\
\text { lenia sztyw- } \\
\text { ności poran- } \\
\text { nej }[0-100]\end{array}$ & 8 & $-30,0$ & $-35,0$ & 25,1 & 6 & $-21,7$ & $-25,0$ & 19,4 & 0,4908 \\
\hline Test HAQ 20 & 8 & $-0,4$ & $-0,3$ & 0,8 & 6 & $-0,6$ & $-0,4$ & 0,6 & 0,6620 \\
\hline $\begin{array}{l}\text { Ocena natę- } \\
\text { żenia bólu } \\
\text { W skali VAS } \\
{[0-100]}\end{array}$ & 8 & $-3,3$ & $-3,5$ & 2,1 & 6 & $-2,5$ & $-2,5$ & 1,5 & 0,4908 \\
\hline $\begin{array}{l}\text { Test zadanio- } \\
\text { wy [s] }\end{array}$ & 15 & $-16,9$ & $-11,0$ & 33,8 & 11 & $-6,4$ & $-16,0$ & 27,5 & 0,6461 \\
\hline $\begin{array}{l}\text { Objętość ręki } \\
{\left[\mathrm{mm}^{3}\right]}\end{array}$ & 16 & 6 & 6 & 26 & 12 & -25 & -25 & 23 & $0,0026^{* * *}$ \\
\hline $\begin{array}{l}\text { Powierzch- } \\
\text { nia ręki } \\
{\left[\mathrm{mm}^{2}\right]}\end{array}$ & 12 & -3 & -41 & 542 & 10 & -151 & -192 & 721 & 0,4965 \\
\hline
\end{tabular}

ard with holes was placed on the table in front of a patient. The peg container was placed by the board on the side of the examined hand. The duration of task performance was measured.

The therapy involved motor improvement as well as a series of magnetotherapy treatments. Individuals who qualified for the study were randomly (coin tossing) divided into two groups. The first group ( 8 persons/16 upper limbs) was treated with static magnetic field, while the other group ( 6 persons/12 upper limbs) was exposed to pulsed magnetic field. The treatments were administered using MF-10 apparatus that generated static field (sequence 5) and pulsed field (sequence 2 - bipolar rectangle at a frequency of $15 \mathrm{~Hz}$ ). For both sequences, a maximal value of magnetic field induction was $5.25 \mathrm{mT}$.

The examinations were carried out twice, i.e. prior to and after the therapy.

Statistical analysis was based on:

- descriptive statistics;

- the Wilcoxon test for evaluating the significance of changes resulting from the therapy;

- the Mann-Whitney test for determining therapeutic effectiveness of the fields.

Statistical significance was set at $\mathrm{p}<0.05$.

\section{Results}

The summary table includes descriptive characteristics of therapy outcomes for both groups as well as the significance of differences between the groups assessed with the use of the Mann-Whitney test (tab. 1).

Tab. 1. Therapy outcomes in both groups

\begin{tabular}{|l|c|c|c|c|c|c|c|c|c|}
\hline \multirow{2}{*}{$\begin{array}{l}\text { Therapy } \\
\text { outcomes }\end{array}$} & \multicolumn{7}{|c|}{ Static/pulsed magnetic field } & \multirow{2}{*}{$p$} \\
\cline { 2 - 8 } & $N$ & & Me & $s$ & $N$ & & Me & $s$ & \\
\hline $\begin{array}{l}\text { Duration of } \\
\text { morning stiff- } \\
\text { ness [min.] }\end{array}$ & 8 & -37.5 & -30.0 & 41.7 & 6 & -21.7 & -20.0 & 23.2 & 0.6620 \\
\hline $\begin{array}{l}\text { Severity of } \\
\text { morning stiff- } \\
\text { ness [0-100] }\end{array}$ & 8 & -30.0 & -35.0 & 25.1 & 6 & -21.7 & -25.0 & 19.4 & 0.4908 \\
\hline HAQ 20 & 8 & -0.4 & -0.3 & 0.8 & 6 & -0.6 & -0.4 & 0.6 & 0.6620 \\
\hline $\begin{array}{l}\text { Pain intensity } \\
\text { according to } \\
\text { VAS [0-100] }\end{array}$ & 8 & -3.3 & -3.5 & 2.1 & 6 & -2.5 & -2.5 & 1.5 & 0.4908 \\
\hline Task [s] & 15 & -16.9 & -11.0 & 33.8 & 11 & -6.4 & -16.0 & 27.5 & 0.6461 \\
\hline $\begin{array}{l}\text { Hand volume } \\
\text { [mm }{ }^{3} \text { ] }\end{array}$ & 16 & 6 & 6 & 26 & 12 & -25 & -25 & 23 & $\mathbf{0 . 0 0 2 6 * *}$ \\
\hline $\begin{array}{l}\text { Palmar sur- } \\
\text { face area } \\
\text { [mm }{ }^{2} \text { ] }\end{array}$ & 12 & -3 & -41 & 542 & 10 & -151 & -192 & 721 & 0.4965 \\
\hline
\end{tabular}




\begin{tabular}{|l|c|c|c|c|c|c|c|c|c|}
\hline $\begin{array}{l}\text { Zakres ruchu } \\
\text { ręki [mm] }\end{array}$ & 12 & $-0,3$ & 1,0 & 3,7 & 10 & 4,7 & 5,2 & 3,9 & $\mathbf{0 , 0 0 9 0 * *}$ \\
\hline $\begin{array}{l}\text { Siła ścisku } \\
\text { ręki [kPa] }\end{array}$ & 12 & 4,3 & 0,7 & 12,3 & 10 & 12,1 & 5,1 & 13,2 & 0,0692 \\
\hline $\begin{array}{l}\text { Czas utrzy- } \\
\text { mania maks. } \\
\text { siły ścisku } \\
{[\mathrm{s}]}\end{array}$ & 12 & 0,0 & 0,8 & 1,7 & 10 & $-0,6$ & 0,4 & 3,1 & 0,4965 \\
\hline
\end{tabular}

p - wartość prawdopodobieństwa testowego obliczona za pomocą testu Manna-Whitneya

Średnie skrócenie czasu utrzymywania się sztywności porannej było nieco większe w grupie poddanej działaniu stałego pola magnetycznego $(37,5 \mathrm{~min}$. vs. 21,7 min.), ale różnica nie była znamienna statystycznie $(p>0,05)$. Średnie obniżenie poziomu nasilenia sztywności było również nieco większe w grupie poddanej działaniu stałego pola magnetycznego $(30,0$ vs. 21,7), ale różnica nie była znamienna statystycznie $(\mathrm{p}<0,05)$ (Tab. 1)

Nie było istotnych statystycznie różnic pomiędzy badanymi grupami w zakresie zmian wyników testu HAQ-20 $(p>0,05)$ jakkolwiek średnia zmiana tego wyniku była nieco większa w grupie leczonej polem pulsującym (-0,6 pkt. vs. -0,4 pkt.) (Tab. 1). Ilustrację przeprowadzonej analizy stanowi wykres średnich zmian wyników testu HAQ - 20 w obu grupach wraz z zakresem typowych przedziałów zmienności oraz naniesionymi $\mathrm{w}$ formie wykresu rozrzutu dokładnymi zmianami wyników testu HAQ-20 dla poszczególnych badanych z obu grup (ryc. 2).

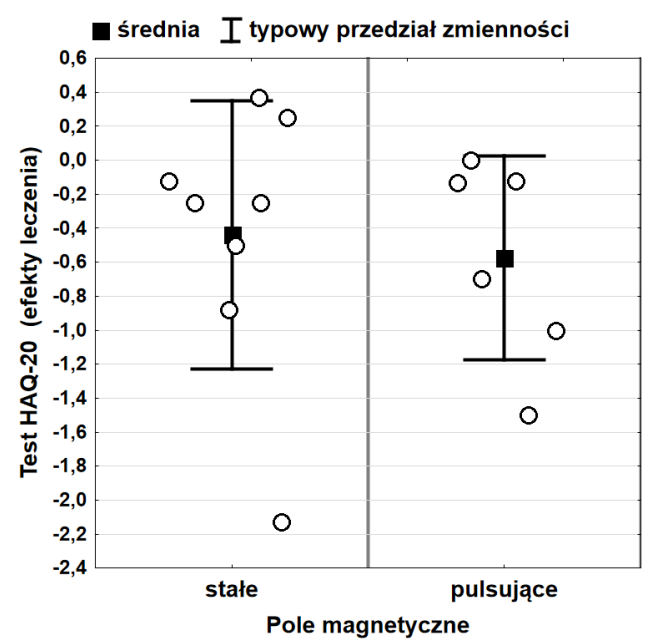

Ryc.2. Średnia zmiana wyniku testu HAQ-20 w obu grupach i zmiany odnotowane u poszczególnych badanych

Średnie obniżenie poziomu bólu również było nieco większe w grupie poddanej działaniu stałego pola magnetycznego (-3,3 pkt. vs. $-2,5$ pkt.), ale różnica nie była znamienna statystycznie $(p>0,05)$ (Tab. 1$)$

Kolejne analizy dotyczyły poszczególnych rąk, dlatego też liczba analizowanych przypadków była większa, co umożliwiło zaprezentowanie wybranych wyników na wykresach rozrzutu.

\begin{tabular}{|l|c|c|c|c|c|c|c|c|c|}
\hline $\begin{array}{l}\text { Range of } \\
\text { motion of the } \\
\text { hand [mm] }\end{array}$ & 12 & -0.3 & 1.0 & 3.7 & 10 & 4.7 & 5.2 & 3.9 & $\mathbf{0 . 0 0 9 0 * *}$ \\
\hline $\begin{array}{l}\text { Grip strength } \\
\text { [kPa] }\end{array}$ & 12 & 4.3 & 0.7 & 12.3 & 10 & 12.1 & 5.1 & 13.2 & 0.0692 \\
\hline $\begin{array}{l}\text { Duration of } \\
\text { sustained } \\
\text { maximal grip } \\
\text { strength [s] }\end{array}$ & 12 & 0.0 & 0.8 & 1.7 & 10 & -0.6 & 0.4 & 3.1 & 0.4965 \\
\hline
\end{tabular}

$p$ - probability value was calculated by means of the Mann-Whitney test (wartość prawdopodobieństwa testowego obliczona za pomocą testu Manna-Whitneya)

A mean decrease in the duration of morning stiffness was slightly larger in the group exposed to static magnetic field ( 37.5 mins vs. 21.7 mins); however, the difference was not significant $(p>0.05)$. A mean decrease in the levels of stiffness severity was also a little larger in the group where static magnetic field was administered (30.0 vs. 21.7$)$ but the difference was not significant $(p<0.05)$ (Tab. 1)

No significant differences were found in the groups in terms of changes in HAQ-20 outcomes $(p>0.05)$. However, a mean outcome change was slightly greater in the group treated with pulsed magnetic field (-0.6 pts vs. -0.4 pts) (Tab. 1). The analysis is illustrated with a graph that shows mean changes in HAQ - 20 outcomes in both groups with standard ranges of variability and a scatter diagram of accurate changes in HAQ-20 outcomes in patients from both groups (fig. 2).

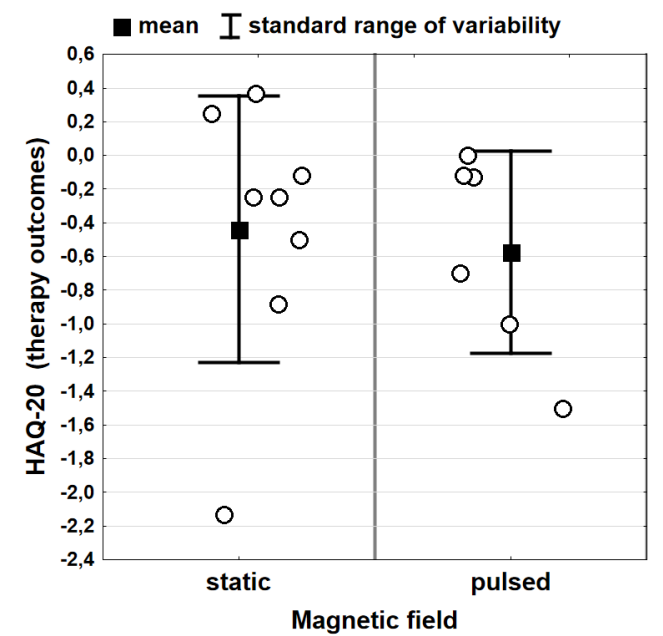

Fig. 2. Mean changes in HAQ-20 outcomes in both groups and in individual patients

A mean decrease in pain intensity was also a little larger in the group exposed to static magnetic field $(-3.3$ pts vs. -2.5 pts $)$ but the difference was not significant $(p>0.05)$ (Tab. 1)

Subsequent analysis focused on particular upper limbs. Therefore, more cases were analysed, which enabled us to present selected results in the form of scatter diagrams. 
Nie było statystycznie istotnych różnic w efektach rehabilitacji pomiędzy grupą leczoną za pomocą pola magnetycznego stałego i pulsującego w zakresie wyników testu zadaniowego $(p>0,05)$. Średni poziom redukcji czasu wykonania zadania był nieco większy w grupie poddanej działaniu stałego pola magnetycznego (-16,9 sek vs. -6,4 sek) (Tab. 1).

Ilustrację przeprowadzonej analizy stanowi wykres wartości średnich efektów leczenia w obu grupach, wraz zakresem typowych przedziałów zmienności oraz naniesionymi $\mathrm{w}$ formie wykresu rozrzutu dokładnymi pomiarami dla wszystkich analizowanych rąk w obu badanych grupach (Ryc. 3).

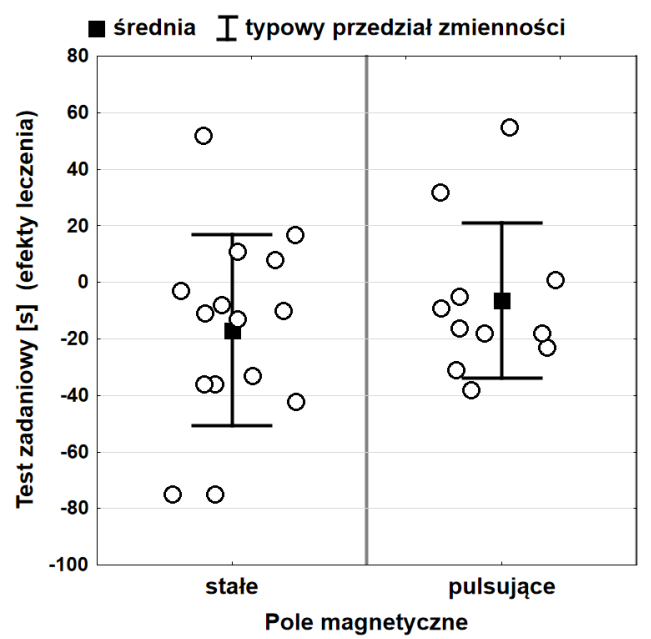

Ryc. 3. Średnia zmiana wyników testu zadaniowego w obu grupach i zmiany odnotowane w poszczególnych rękach

Odnotowano wysoce istotną statystycznie różnicę pomiędzy obiema grupami w zakresie zmian objętości ręki $(\mathrm{p}<0,01)$. W grupie poddanej działaniu pulsującego pola magnetycznego zaobserwowano zmniejszenie objętości (średnio o $25 \mathrm{~mm}^{3}$ ), zaś w grupie poddanej działaniu pola stałego niewielki przyrost objętości (średnio o $6 \mathrm{~mm}^{3}$ ) (Tab. 1).

Efekt leczenia wyrażony zmianą objętości ręki był znamienny w grupie poddanej działaniu pola przerywanego (Ryc. 4).
There were no significant differences in therapy outcomes between both groups in regard to task results $(p>0.05)$. A mean decrease in the duration of task performance was slightly larger in the group where static magnetic field was applied (-16.9 sec. vs. -6.4 sec.) (Tab. 1). The analysis is illustrated with a graph which shows mean values of therapy outcomes in both groups with standard ranges of variability and a scatter diagram of accurate measurements of all the analysed upper limbs (fig. 3).

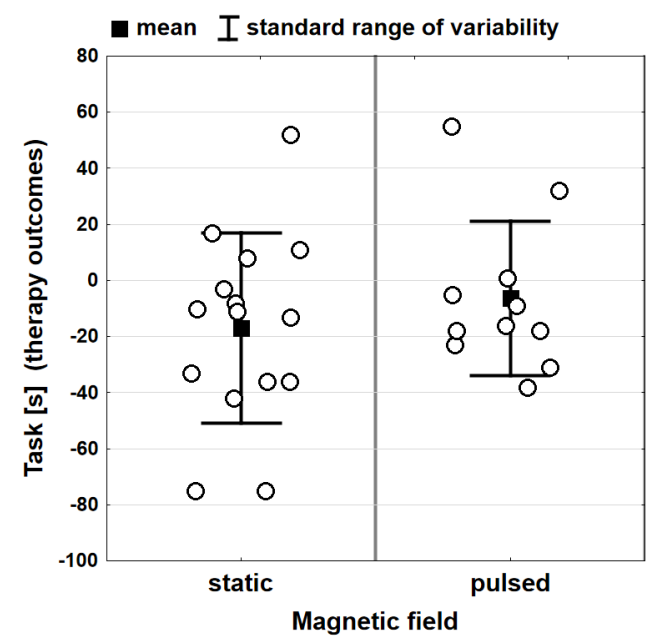

Fig. 3. Mean changes in task results in both groups and in upper limbs

A highly significant difference $(p<0.01)$ between the two groups regarding changes in hand volume was found. A decrease in volume (by an average of $25 \mathrm{~mm}^{3}$ ) was noted in the group that underwent the pulsed magnetic field therapy, whereas a small increase in volume (by an average of $6 \mathrm{~mm}^{3}$ ) was observed in the group exposed to the static magnetic field therapy (Tab. 1).

Changes in hand volume (as therapy outcomes) were significant in the group where pulsed field was administered (Fig. 4). 


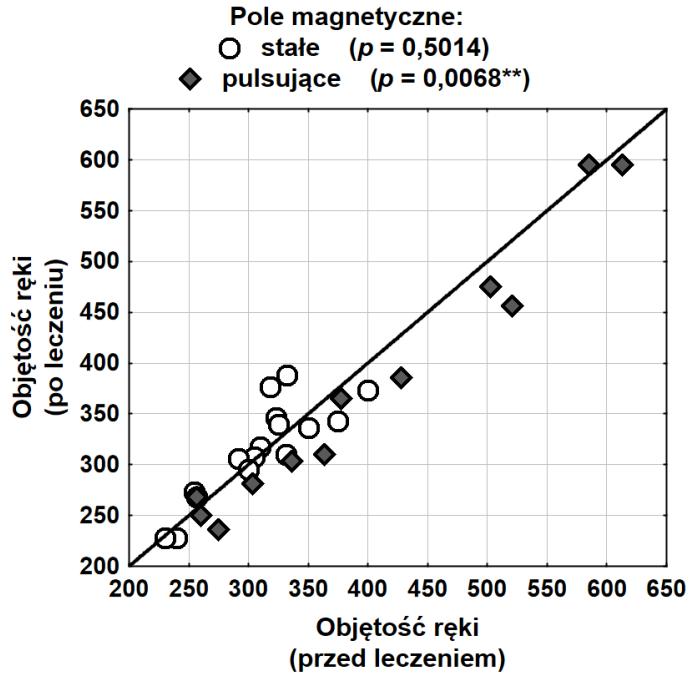

Ryc.4. Zmiany objętości ręki w badanych grupach

Nie było istotnych statystycznie różnic pomiędzy badanymi grupami w zakresie zmian powierzchni dłoniowej ręki. Wprawdzie średnia zmiana powierzchni dłoniowej ręki była większa $w$ grupie poddanej działaniu pulsującego pola magnetycznego (-151 mm2 vs. -3 $\mathrm{mm} 2$ ), ale różnica nie była znamienna statystycznie (p $>0,05)$ (Tab. 1). Średnią zmianę powierzchni dłoniowej ręki oraz zmiany odnotowane u poszczególnych badanych $\mathrm{z}$ obu grup przedstawiono na wykresie rozrzutu z naniesionymi średnimi zmianami wyników i zakresem typowych przedziałów zmienności (Ryc. 5).

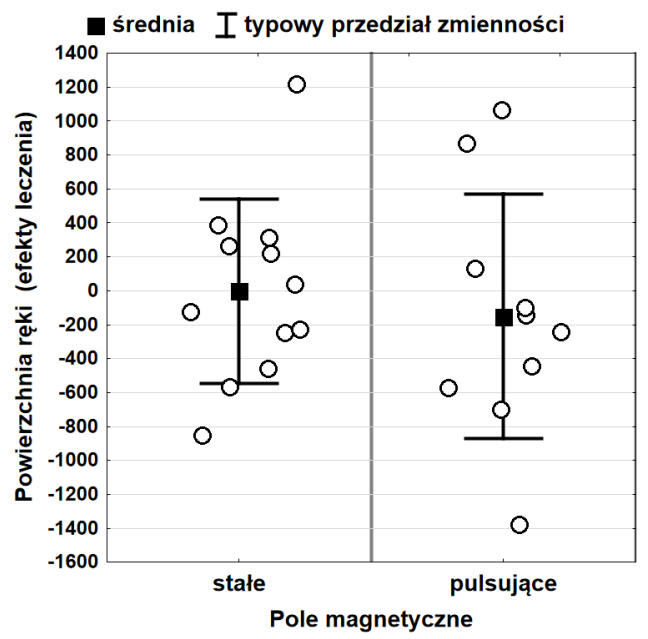

Ryc.5. Średnia zmiana powierzchni dłoniowej ręki w obu grupach i zmiany odnotowane w poszczególnych rękach

Odnotowano wysoce istotną statystycznie różnicę pomiędzy badanymi grupami w zakresie zmian zakresu ruchu w stawach ręki $(\mathrm{p}<0,01)$. W grupie poddanej działaniu pulsującego pola magnetycznego odnotowano wzrost zakresu ruchu (średnio o 4,7 mm), zaś w grupie poddanej działaniu pola stałego niewielkie średnie zmniejszenie zakresu ruchu (średnio o 0,3 mm) (Tab. 1).

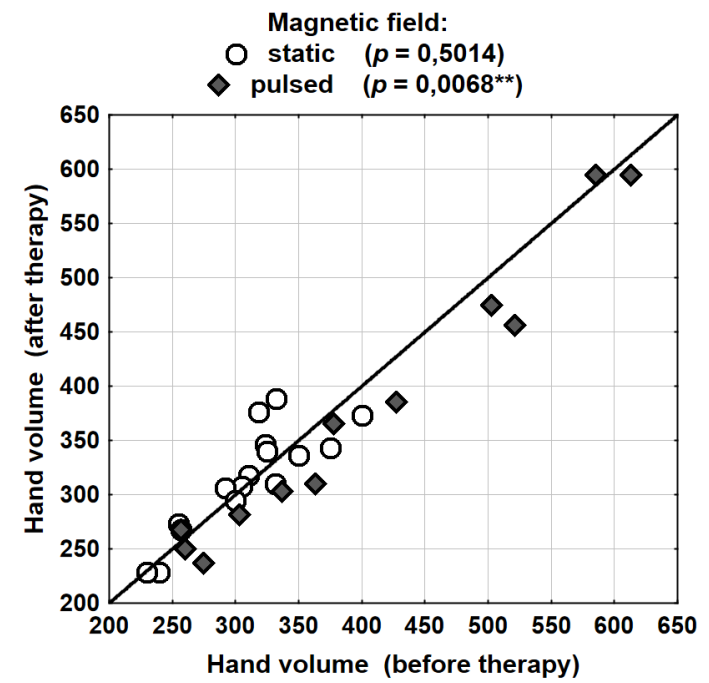

Fig. 4. Changes in hand volume in the studied groups

No significant differences were noted between the groups regarding changes in palmar surface area. Patients exposed to pulsed magnetic field demonstrated a bigger mean change in palmar surface area $(-151$ $\mathrm{mm} 2$ vs. $-3 \mathrm{~mm} 2)$. However, the difference was not significant ( $p>0.05)$ (Tab. 1). Mean changes in palmar surface area and changes noted in patients from both groups are illustrated with a scatter diagram that shows mean result changes and standard ranges of variability (Fig. 5).

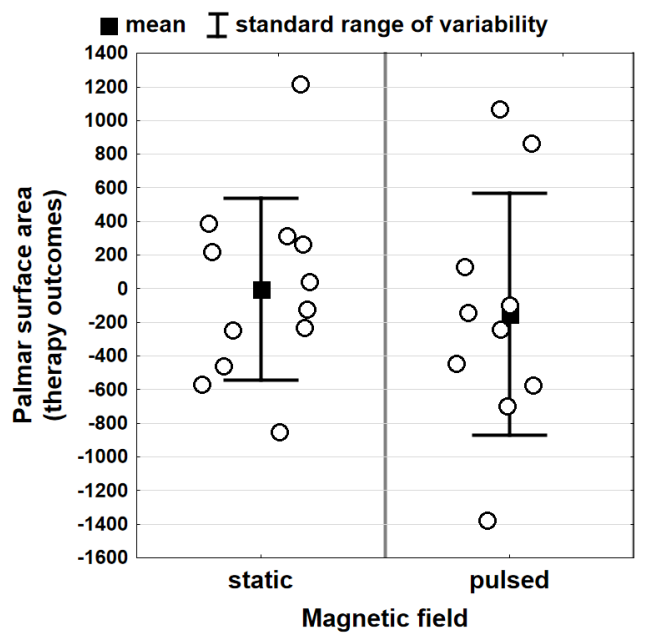

Fig. 5. Mean changes in palmar surface area in both groups and in upper limbs

The analysis revealed highly significant differences between the groups with regard to changes in the range of motion of the hand $(p<0.01)$. Patients from the group that underwent pulsed magnetic field therapy displayed an increase (by an average of 4.7 $\mathrm{mm})$, while those exposed to static field showed a slight mean decrease (by $0.3 \mathrm{~mm}$ ) in the range of motion (Tab. 1). 
Efekt leczenia wyrażony zmianą zakresu ruchu był znamienny w grupie poddanej działaniu pola pulsującego (Ryc. 6).

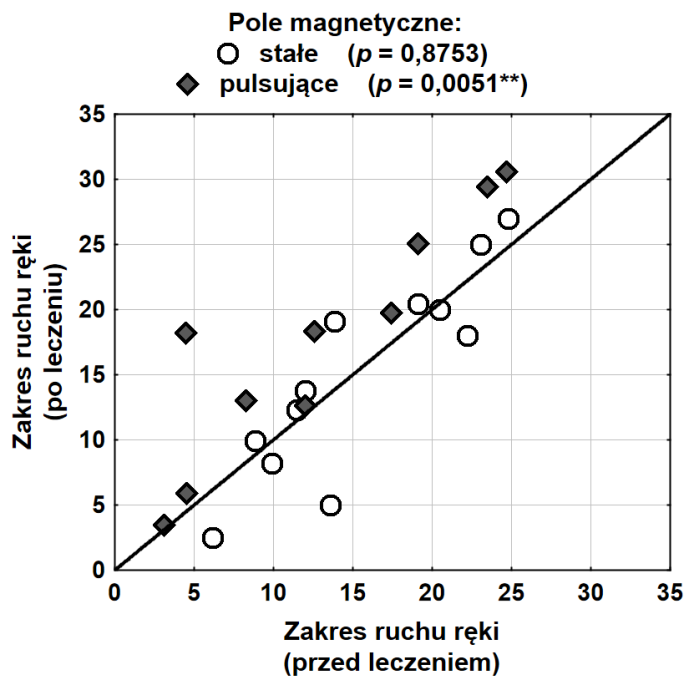

Ryc. 6. Zmiany zakresu ruchu w poszczególnych rękach

Różnica pomiędzy grupami w zakresie zmian siły ścisku ręki była zbliżona do istotnej statystycznie $(\mathrm{p}=0,0692)$. W grupie poddanej działaniu pulsującego pola magnetycznego odnotowano wzrost siły ścisku ręki (średnio o 12,1 kPa), zaś w grupie poddanej działaniu pola stałego wzrost ten wynosił średnio tylko $4,3 \mathrm{kPa}$. (Tab. 1). Efekt leczenia był znamienny w grupie poddanej działaniu pola pulsującego (Ryc. 7).

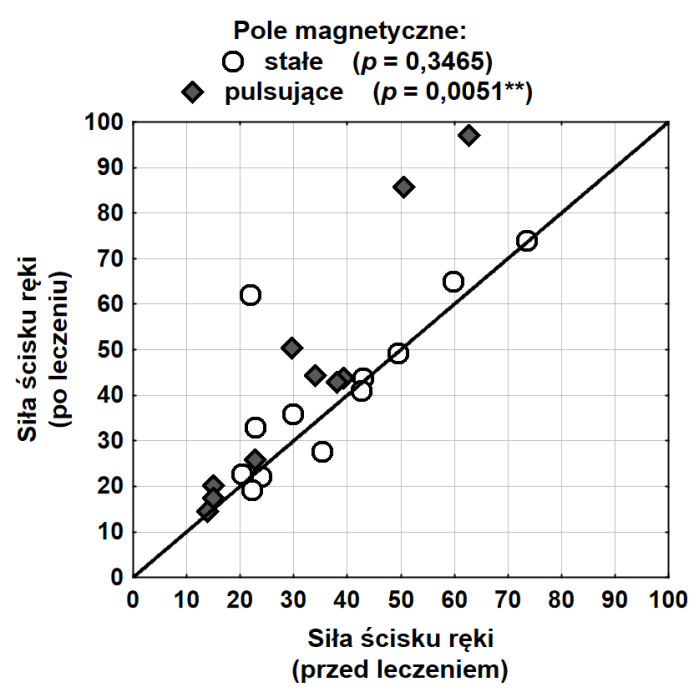

Ryc.7. Zmiany siły ścisku dla poszczególnych rąk

Nie wykazano znamiennych statystycznie różnic pomiędzy obiema grupami w zakresie zmian czasu utrzymania maksymalnej siły ścisku $(p>0,05)$. Średni czas utrzymania maksymalnej siły ścisku pozostał na niezmienionym poziomie $\mathrm{w}$ grupie leczonej polem stałym, zaś w grupie leczonej polem pulsującym średnia zmiana tego czasu wyniosła - 0,6 sek (Tab. 1).
Changes in the range of motion (as therapy outcomes) were significant in the group where pulsed field was administered (Fig. 6).

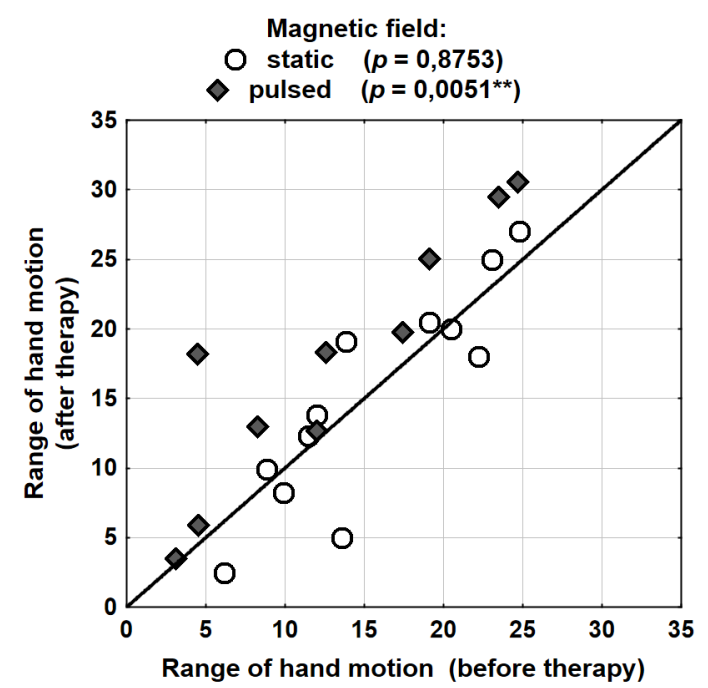

Fig. 6. Changes in the range of motion in upper limbs

The difference between the groups concerning changes in grip strength was almost significant $(p=0.0692)$. Patients after pulsed magnetic field therapy exhibited an increase in grip strength by an average of $12.1 \mathrm{kPa}$, while those who underwent static field therapy improved by $4.3 \mathrm{kPa}$ only (Tab. 1). Therapy outcomes were significant in the group exposed to pulsed field (Fig. 7).

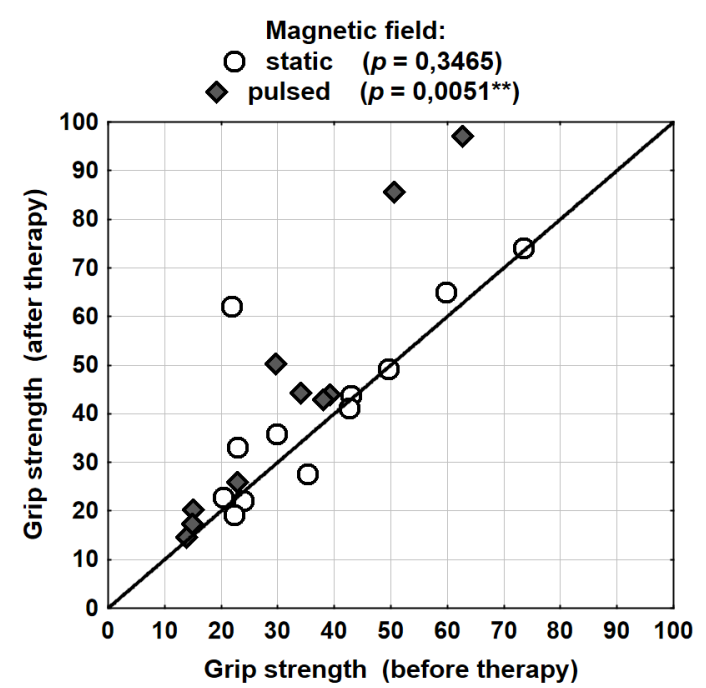

Fig. 7. Changes in grip strength in upper limbs

No significant differences were found in terms of changes in the duration of sustained maximal grip strength $(p>0.05)$. The mean duration of sustained maximal grip strength remained unchanged in the static field group, while in the pulsed field group it changed by $0.6 \mathrm{sec}$ (Tab. 1). In both groups the changes were not significant (Fig. 8). 
W obrębie badanych grup zmiany tego parametru nie były znamienne statystycznie (Ryc. 8).

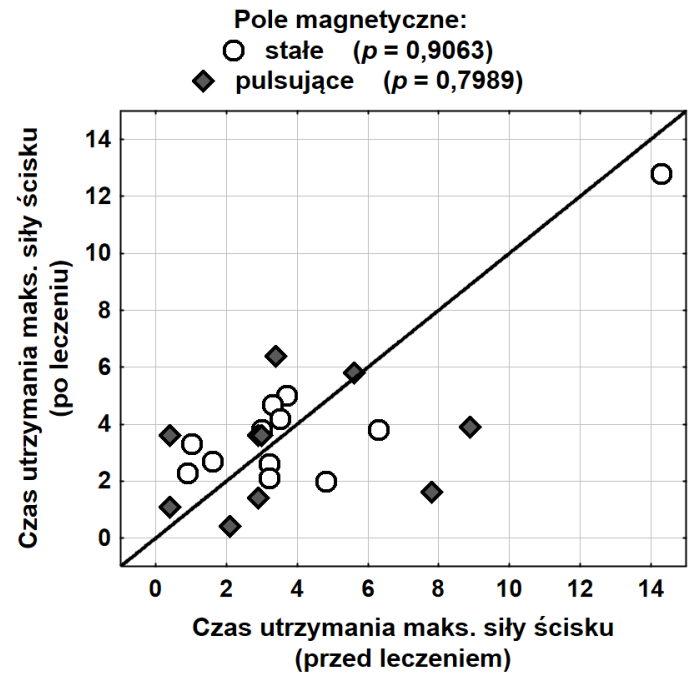

Ryc. 8. Zmiany czasu utrzymania maksymalnej siły ścisku w poszczególnych rękach

\section{Dyskusja}

Pole magnetyczne korzystnie wpływa na mechanizmy regeneracyjne zachodzące $w$ tkankach i pobudza aktywność immunologiczną oraz humoralną całego organizmu [12]. Jest ono powszechnie wykorzystywane w leczeniu pacjentów ze schorzeniami układu kostno-stawowego $[13,14]$. U osób z RZS daje efekt przeciwbólowy, przeciwzapalny i przeciwobrzękowy $[15,16]$. Wykorzystuje się zarówno stałe jak i wolnozmienne pole magnetyczne [17]. Zdaniem Żurawskiego i wsp. (2007) efekty biologiczne terapii są ściśle związane z parametrami aplikowanego pola magnetycznego [18].

$\mathrm{W}$ badaniach z udziałem zwierząt przeprowadzonych przez Dortch i Johnson (2010) potwierdzono przydatność impulsowego pola magnetycznego w leczeniu przewlekłych chorób zapalnych takich jak RZS [7]. Przeciwzapalne działanie takiego pola wykazano także w badaniach Kumar i wsp. (2005). U zwierząt z eksperymentalnie wywołanym procesem zapalnym stosowano unipolarne pole magnetyczne o przebiegu sinusoidalnym i o różnych wartościach indukcji i częstotliwości. Za najbardziej skuteczne uznano pole o wartości indukcji 4 mikrotesli i częstotliwości $5 \mathrm{~Hz}$ z 90 minutowym czasem ekspozycji [19]. W badaniu Chwieśko-Minarowskiej i wsp. (2014) nie potwierdzono skuteczności przeciwbólowej pulsującego pola magnetycznego o częstotliwości od 5 do $23 \mathrm{~Hz}$. Wykazano natomiast, że zastosowanie tego pola daje zmniejszenie liczby obrzękniętych stawów oraz poprawę jakości życia osób z RZS [20].

Badania przeprowadzone przez Segal i wsp. (2001) nie potwierdziły wyższej skuteczności magnesów sta-

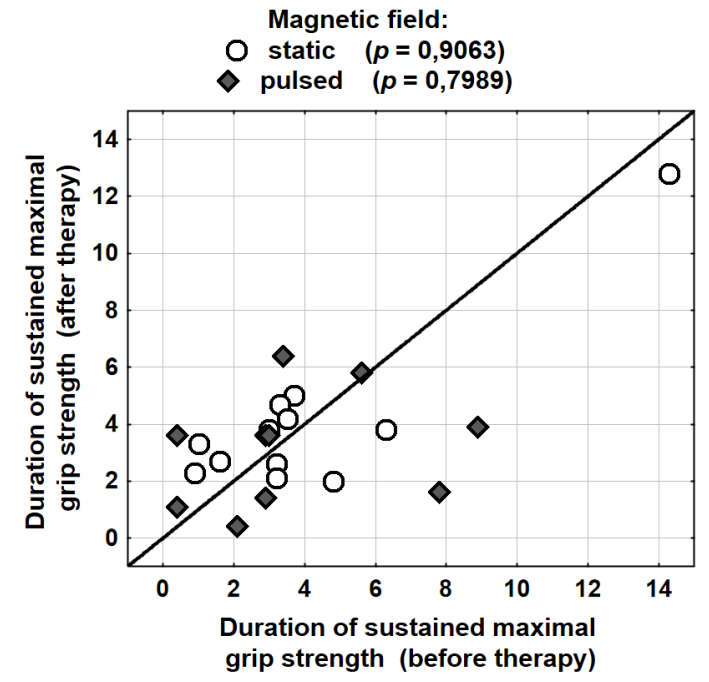

Fig 8. Changes in the duration of sustained maximal grip strength in upper limbs

\section{Discussion}

Magnetic field therapy exerts a positive influence on tissue regeneration processes and stimulates immunological and humoral activity of the whole body [12]. It is commonly applied when treating patients with skeletal system disorders $[13,14]$. In RA patients it has analgesic, antiphlogistic and edema-reducing effects $[15,16]$. Both static and low-frequency magnetic field is used [17]. According to Żurawski et al. (2007), biological effects of the therapy are closely linked to parameters of the applied magnetic field [18].

The research on animals carried out by Dortch and Johnson (2010) confirmed the benefits of pulsed magnetic field in treating chronic inflammatory diseases such as RA [7]. Anti-inflammatory effects of this field were also revealed in the study by Kumar et al. (2005). In animals with induced inflammation, unipolar sinusoidal magnetic field with different induction and frequency values was administered. $4 \mu \mathrm{T} 5 \mathrm{~Hz}$ field with 90-min exposure time was found to be the most effective [19]. Chwieśko-Minarowska et al. (2014) did not note analgesic effects of pulsed magnetic field at a frequency between 5 and $23 \mathrm{~Hz}$. They did note, however, that the application of this field reduced the number of swollen joints and helped to improve life quality of patients with RA [20].

The study conducted by Segal et al. (2001) showed that static magnetic field treatment was not more effective compared to a placebo treatment [21]. Macfarlane et al. (2012) compared the effectiveness of the MagnaBloc device that generated static magnetic field of $190 \mathrm{mT}$ with a similar device generating stat- 
łych w porównaniu do placebo [21]. Natomiast w badaniu włączonym do Macfarlane i wsp. (2012) porównano skuteczność działania urządzenia MagnaBloc generującego statyczne pole magnetyczne o natężeniu $190 \mathrm{mT}$ z podobnym urządzeniem generującym statyczne pole magnetyczne o wartości indukcji magnetycznej $72 \mathrm{mT}$. Wykazano, że zastosowanie wyższej wartości indukcji zapewnia bardziej skuteczne obniżenie aktywności choroby i nasilenia objawów u osób z RZS [4]. W badaniach Greaves i Harlow (2008) oceniano przydatność słabych magnesów $(50 \mathrm{mT})$ do obserwacji efektów placebo w badaniach klinicznych. Autorzy podają, że zastosowano magnesy o sile $180 \mathrm{mT}$ jako magnesy czynne i magnesy $50 \mathrm{mT}$ jako placebo i wnioskują, że magnesy o sile $50 \mathrm{mT}$ nie mogą być wykorzystywane do próby placebo, ponieważ w subiektywnej ocenie pacjenta wykazują efekt terapeutyczny [22]. Z kolei w badaniach Kalmus i wsp. (2010) po zastosowaniu materacy magnetycznych wytwarzających silne pole magnetyczne o maksymalnej indukcji $64 \mathrm{mT}$ odnotowano zmniejszenie wartości CRP, redukcję bólu i poprawę jakości snu [17].

Eccles (2005) po dokonaniu przeglądu literatury dotyczącej skuteczności magnesów stałych wnioskuje, iż opublikowane kontrolowane próby kliniczne potwierdziły działanie analgetyczne tych magnesów [23]. Jednakże, zdaniem Tederko i Krasuskiego, obecny stan wiedzy nie jest wystarczający dla jednoznacznego potwierdzenia skuteczności leczniczej statycznych pól magnetycznych. Urządzenia do takiego oddziaływania nie powinny być wprowadzane na rynek jako sprzęt do magnetoterapii przeznaczonej do wykorzystania w warunkach domowych bez udowodnienia ich skuteczności i bezpieczeństwa [10].

Poziom niepełnosprawności osoby z RZS zależy w dużej mierze od stanu funkcjonalnego ręki [24,25]. $\mathrm{W}$ badaniach własnych w ocenie sprawności manualnej uwzględnione zostały parametry mające kluczowe znaczenie dla takiej oceny. Efekt leczenia w obrębie każdej z badanych grup oceniano za pomocą testu Wilcoxona. Nieznamienne wyniki tego testu spowodowane były tym, że każda z grup analizowana oddzielnie liczyła mniej przypadków w porównaniu do całej zbiorowości.

Pomiary objętości ręki pozwoliły wykazać, że w grupie poddanej działaniu pulsującego pola magnetycznego uzyskano wyraźną redukcję obrzęku ręki. Takich zmian nie odnotowano po leczeniu polem stałym. Pomiary zakresu ruchu potwierdziły poprawę ruchomości w stawach ręki w grupie leczonej polem pulsującym, w której odnotowano redukcję obrzęku. Jednocześnie pole to miało większy wpływ na poprawę siły ścisku ręki, a różnica pomiędzy grupami była zbliżona do istotności statystycznej. Ze względów technicznych komputerowe pomiary powierzchni dłoniowej, zakresu ruchu, siły ścisku ręki i czasu utrzymania maksymalnej siły zostały przeprowadzone u 11 osób (22 ręce). Można przypuszczać, że przy większej liczbie badanych rąk różnica pomiędzy grupami osiągnęłaby poziom istotności $(\mathrm{p}<0.05)$. Brak ic magnetic field of $72 \mathrm{mT}$. It was revealed that the treatment with stronger magnetic field led to a more effective decrease in disease activity and intensity of symptoms in patients with RA [4]. Greaves and Harlow (2008) explored the validity of weak magnets (50 $\mathrm{mT}$ ) as a placebo in clinical trials. They used magnets of $180 \mathrm{mT}$ as active magnets and magnets of $50 \mathrm{mT}$ as a placebo. They concluded that $50 \mathrm{mT}$ magnets could not be used in placebo tests because patients believed they produced therapeutic effects [22]. In turn, Kalmus et al. (2010) observed a decrease in CRP levels, pain reduction and sleep quality improvement after implementing magnetic mattresses generating strong magnetic field (up to $64 \mathrm{mT}$ ) [17].

Having reviewed the literature on therapeutic effectiveness of static magnets, Eccles (2005) concluded that published controlled trials proved their analgesic effects [23]. However, Tederko and Krasuski claimed that the current state of knowledge is not sufficient to bear out static magnetic field effectiveness. Devices generating magnetic field should not be marketed as magnetotherapy equipment designed for home use without proving its effectiveness and safety [10].

Disability level in patients with RA depends to a large extent on functional capacity of the hand $[24,25]$. In our research, key parameters of hand mobility were evaluated. Therapy outcomes for each group were assessed using the Wilcoxon test. The fact that each group analysed separately consisted of fewer cases compared to the sample size as a whole resulted in insignificant test outcomes.

Hand volume measurements revealed considerably reduced swelling in the group exposed to pulsed magnetic field. Static field therapy did not lead to such changes. Range of motion measurements showed an improvement in mobility in the joints of the hand in patients treated with pulsed field (the group where reduced swelling was noted). Pulsed field therapy also contributed to an increase in grip strength and the difference between the groups was almost significant. Due to technical reasons, computer-assisted measurements of palmar surface area, range of motion, grip strength and the duration of sustained maximal grip strength were performed on 11 patients (22 upper limbs). It may be assumed that if more upper limbs had been examined, the difference between the groups would have been significant $(p<0.05)$. The lack of significant differences between the groups regarding changes in the duration of sustained maximal grip strength and task results is an argument in favour of carrying on with the research on a larger sample size. Furthermore, differences in the level of motivation of the study participants to achieve satisfactory test outcomes may have affected their performance. Static field seems to be more effective when it comes to relieving pain and morning stiffness symptoms. Nonetheless, the lack of significant differences between the groups prevents us 
istotnych różnic pomiędzy grupami w zakresie zmian czasu utrzymania siły ścisku i wyników testu zadaniowego to argument przemawiający za kontynuacją badań z udziałem bardziej licznej grupy. Można też domniemywać, iż na taki wynik wpłynęła różna motywacja badanych osób do uzyskania zadowalającego wyniku testu.

Pole stałe zdaje się być nieco bardziej skuteczne w redukcji objawów bólu i sztywności porannej, jednak brak istotnej różnicy pomiędzy grupami nie pozwala na jednoznaczne wnioskowanie dotyczące skuteczności tego pola w leczeniu osób z RZS. Zebrane dotychczas wyniki badania zdają się natomiast potwierdzać ogólne założenia teorii jonowego rezonansu cyklotronowego, w myśl której to nie wysoka intensywność pola magnetycznego o niezmiennym przebiegu, ale jego szczególne ukształtowanie w impulsy zapewnia optymalne efekty terapii.

Realizowany projekt badawczy zakłada przeprowadzenie oceny długoterminowej (follow-up) co umożliwiłoby ocenę trwałości efektów terapii jak też identyfikację ewentualnych czynników mających wpływ na wyniki w trakcie badania krótkoterminowego. Ponadto w badaniach, w których jako narzędzie wykorzystywane są skale jakości życia czy kwestionariusze niepełnosprawności dla uzyskania wiarygodnych wyników niezbędna jest ocena efektów odległych. Tylko nieliczne publikacje naukowe zawierają dokładną charakterystykę jakościową i ilościową stosowanych pól. W przypadku stałych pól magnetycznych nawet o bardzo dużej indukcji magnetycznej, uboczne efekty zdrowotne są rzadko obserwowane i opisywane [26]. Niekiedy, tak jak w przeglądzie Macfarlane i wsp. (2012) czy w badaniu Greaves i Harlow (2008) przytaczane wartości indukcji dla stałego pola magnetycznego wykorzystywanego w badaniach klinicznych są wyjątkowo wysokie (190 czy 180 militesli).

Wiedza dotycząca mechanizmu oddziaływania tego pola na żywe organizmy, stosowanych dawek jak też wskazań i przeciwwskazań do zabiegu wciąż pozostawia wiele niejasności. Uściślenie optymalnych parametrów zabiegowych magnetoterapii wymaga kontynuacji badań z udziałem bardziej licznej i jednorodnej grupy badanych z uwzględnieniem efektów odległych. Rzetelnie przeprowadzone badania kliniczne o wysokiej jakości metodologicznej pozwolą ocenić wpływ pola magnetycznego na organizm ludzki z uwzględnieniem charakteru pola $\mathrm{i}$ innych parametrów zabiegu. Wyniki takich badań są niezbędne dla uściślenia metodologicznych podstaw stosowania pól magnetycznych w medycynie.

\section{Wnioski}

1. Pulsujące pole magnetyczne aplikowane na okolicę rąk u osób z RZS jest bardziej skuteczne w redukcji obrzęku, poprawie zakresu ruchu i siły mięśniowej ręki w porównaniu do stałego pola magnetycznego. from drawing valid conclusions concerning static field therapy effectiveness in individuals with RA. The data collected so far appear to confirm general assumptions of the ion cyclotron resonance theory, which says that it is not high intensity of static magnetic field but specific types of pulsed magnetic field that ensure optimal therapy effects.

Our research project involves a long-term patient follow-up evaluation. This will enable us to assess retention of therapy effects and determine possible factors affecting findings from a short-term study. Moreover, when quality of life scales or disability questionnaires are used to obtain reliable data, it is necessary to assess long-term effects. Only a few publications provide accurate qualitative and quantitative characteristics of the fields applied. Even in the case of magnetic fields with large magnetic induction, health-related side effects are rarely reported [26]. In the review by Macfarlane et al. (2012) or in the study by Greaves and Harlow (2008), static magnetic field induction applied in clinical trials is exceptionally large (190 or $180 \mathrm{mT})$.

The influence of this field on living organisms, therapeutic doses as well as indications and contraindications to therapy have not been fully investigated as yet. Further studies on a larger and more homogeneous sample size bearing in mind long-term effects are required to specify optimal treatment parameters of magnetotherapy. Properly conducted clinical trials of high methodological quality will make it possible to estimate the influence of magnetic field on a human body taking into account the type of field and other treatment parameters. Findings of such investigations are needed to establish methodological standards for the application of magnetic fields in medicine.

\section{Conclusions}

1. When administered to areas within upper limbs in patients with RA, pulsed magnetic field produced better effects related to the reduction of swelling as well as improving range of motion and muscle strength than static field. 
2. Nie potwierdzono wpływu rodzaju pola magnetycznego na jego skuteczność w obniżaniu bólu, odczuwanej sztywności porannej i poziomu niepełnosprawności ocenianej kwestionariuszem HAQ 20.
2. The findings did not confirm the relationship between the type of magnetic field and its therapeutic effectiveness in reducing pain, morning stiffness and disability level determined with the use of HAQ 20.

\section{Piśmiennictwo/References}

1. Skalska-Izdebska R, Zwolińska J, Weres A, Zając L. Możliwości wykorzystania zmiennego pola magnetycznego w leczeniu schorzeń i urazów narządu ruchu. Zamojskie Studia i Materiały 2006;8(3):167-73.

2. Posłuszny M. Magnetoterapia - terapia naturalna wspomożona osiągnięciami technologii. Wprowadzenie do magnetoterapii. Prakt Fizjoter Rehabil 2015;62(6):16-20.

3. Kubisz L, Werner H, Świdziński T, Hojan-Jezierska D. Pomiar parametrów zmiennego pola magnetycznego niskiej częstotliwości generowanego przez wybrany aparat do magnetoterapii. Now Lek 2010;79(3):199-203.

4. Macfarlane GJ, Paudyal P, Doherty M, Ernst E, Lewith G, MacPherson H. et.al. A systematic review of evidence for the effectiveness of practitioner-based complementary and alternative therapies in the management of rheumatic diseases: rheumatoid arthritis. Rheumatology 2012;51(9):1707-13.

5. Chmara E, Cieślewicz A. Niefarmakologiczne metody leczenia bólu. Farm Współcz 2010;3:15-9.

6. Richmond SJ. Magnet therapy for the relief of pain and inflammation in rheumatoid arthritis (CAMBRA): A randomized placebo-controlled crossover trial. Trials 2008;12(9):53.

7. Dortch AB, Johnson MT. Characterization of pulsed magnetic field therapy in a rat model for rheumatoid arthritis. Biomed Sci Instrum 2006;42:302-7.

8. 8. Żurawski P, Stryła W. Efekty biologiczne oddziaływania na człowieka pól elektromagnetycznych niskich częstotliwości. Probl Hig 2011;92(2):167-72.

9. Gajewski M, Rzodkiewicz P, Maśliński S, Wojtecka-Łukasik E. The role of physiological elements in future therapies of rheumatoid arthritis. III. The role of the electromagnetic field in regulation of redox potential and life cycle of inflammatory cells. Reumatologia 2015;53(4):219-24.

10. Tederko P, Krasuski M. Oddziaływanie przeciwbólowe magnesów stałych- dowody na skuteczność. Fizjoter Pol 2011;11(4):289-301.

11. Kwolek A, Drużbicki M, Bieniasz W, Zwolińska J, Przysada G. Stanowisko do badań ręki - możliwości zastosowania w rehabilitacji. Post Rehab 2011;49(1):23-28.

12. Posłuszny M. Magnetoterapia w leczeniu osób starszych. Prakt Fizjoter Rehabil 2015;67(12):59-62.

13. Gąsiorowski J, Sciepurko J. Magnetoterapia- bezpieczna alternatywa w walce z bólem. Prakt Fizjoter Rehabil 2014;48(3):32-3.

14. Johnson MT, Waite LR, Nindl G. Noninvasive treatment of inflammation using electromagnetic fields: current and emerging therapeutic potential. Biomed Sci Instrum 2004;40:469-74.

15. Giordano N, Battisti E, Geraci S, Santacroce C, Lucani B, Fortunato M. et al. Analgesic-antiinflammatory effect of a $100 \mathrm{~Hz}$ variable magnetic field in RA (letter). Clin. Exp Rheumatol 2000;18(2):263.

16. Skalska-Izdebska R, Fatyga P, Szczypiorowska-Goraj B, Kurach A, Pałka T. Ocena skuteczności fizykoterapii w leczeniu reumatoidalnego zapalenia stawów. Young Sport Science of Ukraine 2012;3:205-15.

17. Kalmus P, Pracka D, Pracki T, Szulc K, Szynkowska L, Matzkeit O. Ocena skuteczności stałego, naprzemiennego pola magnetycznego w wybranych aspektach terapii pacjentów z chorobami reumatologicznymi. Acta Balneol 2010;52(2):84-9.

18. Żurawski P, Naskręcki R, Michalak M, Jadżyn M, Stryła W, Knapczyk M. Pomiar parametrów pola elektromagnetycznego niskiej częstotliwości stosowanego w fizykoterapii. Fizjoter Pol 2007;7(1):45-51.

19. Kumar VS, Kumar DA, Kalaivani K, Gangadharan AC, Raju KV, Thejomoorthy P. et.al. Optimization of pulsed electromagnetic field therapy for management of arthritis in rats. Bioelectromagnetics 2005;26(6):431-9.

20. Chwieśko-Minarowska S, Kuryliszyn-Moskal A, Pijanowska M, Jabłońska M. The comparison of multi-waved locked system laser and low-frequency magnetic field therapy on hand function and quality of life in patients with rheumatoid arthritis - preliminary study. Acta Balneol 2014;56(4):181-4.

21. Segal NA, Toda Y, Huston J, Saeki Y, Shimizu M, Fuchs H. et.al. Two Configurations Of Static Magnetic Fields For Treating Rheumatoid Arthritis Of The Knee: A Double-Blind Clinical Trial. Arch Phys Med Rehabil 2001;82(10):1453-60.

22. Greaves CJ, Harlow TN. Exploration of the validity of weak magnets as a suitable placebo in trials of magnetic therapy. Complement Ther Med 2008;16(3):177-80.

23. Eccles NK. A critical review of randomized controlled trials of static magnets for pain relief. J Altern Complement Med 2005;11(3):495-509.

24. Migut N, Kwolek A, Zwolińska J. Wpływ postępowania rehabilitacyjnego na czynność ręki u kobiet z reumatoidalnym zapaleniem stawów. Zamojskie Studia i Materiały 2013; 15(2):21-32.

25. Drużbicki M, Zwolińska J, Przysada G, Maj M. Assessment of hand mobility in patients with rheumatoid arthritis using a computer measurement station. Reumatologia 2013;51:133-8.

26. ICNIRP. Statement on medical magnetic resonance (MR) procedures: protection of patients. Published in: Health Phys 2009;97(3):259-261. 